\title{
US increases health funds but ducks AIDS allocation
}

\section{IMAGE UNAVAILABLE FOR COPYRIGHT REASONS}

Cause for reflection: the French Thémis plant could be used to detect gamma rays.

- a big experiment, probably at Solar Two. With its 2,000 mirrors, each with an area of 40 square metres, Solar Two has the potential to be "the most powerful and sensitive gamma-ray observatory", says Ong.

But not everyone agrees. Trevor Weekes, head of the gamma-ray astronomy group at the Whipple Observatory, believes that makeshift facilities at solar farms cannot be substituted for fully fledged observatories. $\mathrm{He}$ says that the long-term monitoring needed to characterize gamma-ray sources can be done only with a dedicated telescope.

"The solar arrays in Barstow and Thémis have sufficient mirror area to extend ground-based gamma ray detection techniques to lower energies. However, if one were to design an atmospheric Cherenkov telescope from scratch, one would never design the mirrors in this configuration, nor is it likely that one would locate the telescope at these sites."

At best, he says, solar farm instruments can "fill the gap temporarily" before the next-generation space observatory (such as the yet-to-be-approved GLAST telescope ) and ground-based observatory (such as the proposed \$10-million ATHENA project at Whipple) become available.

Ong replies: "It could be 10 years before either project comes to fruition, and some interesting science might be done in the meantime." A participant in GLAST, Ong is as anxious as anyone to see the mission fly. But he says the mirrors on the proposed space observatory would not be big enough to detect weak sources. And ATHENA would focus on higher-energy gamma rays than STACEE and CELESTE.

Ong agrees with Weekes that a solar farm 'telescope' will fall short of the "ultimate" gamma-ray observatory. But to build such a mirror from scratch would cost $\$ 100$ million.

Steve Nadis
Washington. The budget for the National Institutes of Health (NIH) in the 1997 fiscal year, which began on 1 October, will - as widely anticipated - be 6.9 per cent higher than the 1996 budget, under a bill passed by the US Congress and signed by President Clinton late on Monday. But it has sparked controversy over its failure to specify how much should be spent on AIDS research.

The NIH budget, which will total $\$ 12.7$ billion, includes $\$ 90$ million to begin the construction of the planned Clinical Research Center on the NIH campus. "I'm extremely pleased," said John Porter (Republican, Illinois), chairman of the House labor, health and human services and education appropriations subcommittee, who authored the 6.9 per cent funding increase and persuaded colleagues to adopt it over the more modest 4.1 per cent increase proposed in the Senate.

The budget law also includes a new compromise on the status of the NIH's politically embattled Office of AIDS Research (OAR). Under this, the office will be allowed to determine how much money is spent on AIDS, to allocate this between the NIH's 24 institutes, divisions and centres, and to shift funds between institutes during the year, within limits. The power to shift this money - up to $\$ 45$ million - is a new one, aiming to allow the OAR to respond to changing research developments.

But, reflecting the fact that some House Republicans have opposed earmarking money for AIDS, the measure does not specify how much of the NIH budget should be spent on AIDS research - although this was required by the 1993 law that established the current powers of the OAR. Instead, it says merely that Harold Varmus, the director of NIH, and William Paul, the director of OAR, will jointly agree a figure.

A report accompanying the budget law sets this figure at $\$ 1.5$ billion, a 6.6 per cent increase over 1996. "This simply gives [Paul] appropriation authority, without providing a line item that would be diseasespecific," said Porter. "It preserves our very strong intent that science determine the allocation of funding for research, and not politics."

Speaking after house passage of the bill, Paul said the NIH would have preferred a single-line item in the budget, known as a 'consolidated appropriation'. But the bill as written nonetheless grants the OAR much of the same flexibility as before, "and in some respects goes beyond" former limits, he says, referring to the power to transfer funds between institutes.

But AIDS activists, the Clinton administration and some scientists called the compromise a partisan political gambit that ignores the wishes of the scientific community. "The scientists want [the strongest possible OAR]. That's what's so galling about Porter's attitude," said one AIDS scientist.

Gregg Gonsalves, policy director with Treatment Action Group, a national organization that lobbies for AIDS research, said the deal was made "in the best interest of right wing politics". A Clinton administration official who follows the issue admits that "our absolute preference [was] to have the full authority of the OAR", but adds that "we continued to run into a brick wall in the House".

OAR supporters also worry that, if voters return a republican congress in November's elections, the compromise could hurt their position in imminent negotiations to renew the 1993 law that established the OAR as overseer of NIH AIDS research.

Nevertheless the compromise is the closest thing yet to a truce in a political battle which has beset the OAR since 1993, when it was first put in full charge of the AIDS research portfolio. According to one Congressional staff member, neither side can complain too loudly about the arrangement, because it does two things. It allows Porter to say there is no earmark for AIDS in the 1997 spending bill, and it allows Paul to control AIDS funds.

Congressional conservatives have protested that the OAR's control over nearly 12 per cent of the NIH's budget puts AIDS on a pedestal not granted other diseases, at the urging of AIDS activists. But the office is also backed by many scientists, including Nobel laureates David Baltimore of the Massachusetts Institute of Technology, and Torsten Weisel, president of Rockefeller University.

The latter were among more than 350 scientists who signed letters this year to Congressional leaders urging that the OAR keep its full authority. Last March, a committee of 118 experts headed by Arnold Levine, a molecular biologist at Princeton University, recommended that the office should retain its full power over the AIDS purse strings $-\$ 1.4$ billion in the 1996 fiscal year.

This summer, the House passed a 1997 spending bill which restricted the OAR's authority, as did the republican-authored law which funded the OAR in the 1996 fiscal year. The parallel Senate bill did not restrict the OAR, but it did not reach a vote. The new bill gives OAR the flexibility to transfer between institutes during the year up to three per cent of a given institute's AIDS budget.

Meredith Wadman 